Jurnal Konstruksi Hukum | ISSN: 2746-5055

Vol. 2, No. 2, Mei 2021 Hal. 260-264| Tersedia online ।

https://www.ejournal.warmadewa.ac.id/index.php/juk

DOI: https://doi.org/10.22225/jkh.2.2.3217.260-264

\title{
WEWENANG KEPOLISIAN DALAM PENYIDIKAN TINDAK PIDANA NARKOTIKA
}

\author{
Sri Ulina Theresa Perangin-Angin, Anak Agung Sagung Laksmi Dewi, Ni Made Sukaryati Karma \\ Fakultas Hukum Universitas Warmadewa, Denpasar-Bali, Indonesia \\ thesa.ulina2899@gmail.com, laksmiidewi29@gmail.com, madesukaryatikanna@gmail.com
}

\begin{abstract}
Abstrak
Polisi memiliki kewenangan yang sangat luas dalam menegakkan hukum dan menjamin keamanan serta ketertiban masyarakat. Peran dan wewenang polisi, menjadi panutan dan pengharapan warga terhadap tugas Kepolisian Negara Republik Indonesia yang semakin tinggi dan memiliki orientasi kepada warga yang dilayani. penelitian ini bertujuan untuk menjelaskan kewenangan penyidik kepolisian dalam penyidikan tindak pidana Narkotika dan menjelaskan mekanisme penyidikan di tingkat penyidikan yang dilakukan oleh polisi sebagai penyidik dalam kasus tindak pidana narkotika. Penelitian ini didesain menggunakan metode penelitian hukum empiris. Sedangkan pendekatannya adalah pendekatan masalah yang digunakan adalah pendekatan antropologi hukurn, krirninologi, viktimologi dan penologi. Sumber data yang digunakan adalah data primer diperoleh dengan cara peneliti mewawancarai informan atau pemberi informasi yang dalam penelitian ini merupakan anggota kepolisian POLDA BALI, data sekunder adalah data yang mendukung atau memperluas data primer yang di dapatkan dari bahan pustaka seperti undang-undang dan keputusan yang mengikat. Data penelitian diperoleh melalui wawancara bersama beberapa pihak tertentu seperti polisi, dengan mekanisme pembicaraan tanya jawab terhadap responden untuk mendapatkan jawaban mengenai penelitian ini. Penganalisaan bahan hukum digunakan denagn teknik deskriptif kualitatif yaitu sebuah metode penelitian yang memanfaatkan data kualitatif yang dijabarkan secara deskriptif dan menghasilkan hasil data yang murni tanpa adanya proses manipulasi arau hal perlakuan lain. Hasl penelitian ini menyimpulkan bahwa kewenangan penyidik polri dalam tindak pidana Narkotika yaitu mengikuti pasal 1 ayat I KUHAP, dan Pasal 81 UU No.35 Tahun 2009 tentang narkotika. Selanjutnya proses penyidikan berpedoman pada Pasal 81, pasal 84, pasal 87, pasal 90, pasal 92 UU No.35 Tahun 2009 tentang Narkotika menjadi acuan dalam melaksanakan proses penyidikan di tingkat penyidikan.
\end{abstract}

Kata Kunci: Narkotika, Penyidikan, Wewenang Kepolisian

\begin{abstract}
The police have authority in enforcing the law and ensuring security and public order. The role and authority of the police, become the role models and expectations of citizens of the increasingly high duties of the Indonesian National Police and have an orientation towards the citizens they serve. This study aims to explain the authority of police investigators in investigating narcotics crime and to explain the investigation mechanism at the level of investigation carried out by the police as investigators in narcotics crime cases. This research was designed using empirical legal research methods. While the approach used is legal anthropology, cryrinology, victimology and penology. The data source used is primary data obtained by the researcher interviewing informant, the POLDA BALI police. Secondary data is data that supports or expands primary data obtained from library materials such as laws and binding decisions. The research data was obtained through interviews with certain parties such as the police, with a question and answer discussion mechanism with respondents to obtain answers about this research. Analysis of legal materials is used with qualitative descriptive techniques, namely a research method that utilizes qualitative data that is described descriptively and produces data results without any manipulation process or other treatment matters. The results of this study concluded that the authority of the police investigator in the crime of narcotics, namely following article 1 paragraph I of the Criminal Procedure Code, and Article 81 of Law No.35 of 2009 on narcotics. Furthermore, the investigation process is guided by Article 81, article 84, article 87, article 90, article 92 of Law No.35 of 2009 on Narcotics as a reference in carrying out the investigation process at the investigation.
\end{abstract}

Keywords: Narcotics, Investigation, Police Authority

\section{PENDAHULUAN}

Indonesia adalah Negara hukum yang berdasarkan Pancasila dan UUD NRI 1945, hukum pada penjelasan tersebut mempunyai arti sangat penting dalam kehidupan bermasyarakat dan juga 
merupakan panutan dalam tingkah laku manusia dalam konteks sosial, tentunya semua itu bertujuan untuk memberikan perbedaan dalam kehidupan masyarakat. Hukum sendiri bersifat mengatur dan memaksa, kejadian ini dapat terlihat dari adanya peraturan UU yang terdapat di Indonesia.

Hukum yang bersifat khusus diatur diluar hukum pidana umumnya, penyimpangan peraturan hukum pidana dalam kitab undang-undang pidana menjadi tolak ukur yang membedakan hukum pidana umum atau hukurn pidana khusus. Dapat dijelaskan ialah hukum tindak pidana khusus adalah undang-undang yang diatur tersendiri diluar dari kitab undang hukum pidana (H.S \& Nurbani, 2013). Wewenang ialah kekuasaan guna melakukan suatu atau memperintahkan orang lain unruk lakukan sesuatu agar tercapainya keinginan tertenru. Sehubung dengan penyidik dan penyelidikan, penyidik merupakan pejabat atau bagian Kepolisian Negara Republik Indonesia yang diberikan suatu kekuasaan dari undang-undang unruk mengerjakan suatu penyelidikan. Penyelidikan yang dimaksud ialah beberapa rangkaian dari tindakan penyidik untuk mencari tahu atau mendapatkan suatu berupa kejadian yang terduga ialah tindak pidana agar bisa ditentukan Ian jut atau tidak penyidikan melihat rangkaian yang di atur didalarn undang-undang (Marbun, 1997). Dalam tindak pidana terdapat tindak pidana khusus pada hal ini akan membahas tindak pidana khusus mengenai Narkotika. Sebetulnya narkotika tersebut bukanlah barang yang ditakutkan bagi masyarakat sebab Narkotika sangat berfungsi dalam dunia medis guna mengobati terhadap penyakit-penyakit tertentu yang membutuhkan kandungan Narkotika tersebut. Selama ini pelanggaran terhadap Narkotika dicemarkan oleh mereka yang tidak mengerti tentang maksud dan tujuan dari obat-obatan tersebut sehingga merusak generasi atau hanya sekedar menikmati dari barang haram tersebut, oleh karena itu banyak terjadi pelanggaran penyalahgunaan Narkotika yang ingin memanfaatkan keadaan guna untuk memperkaya diri sendiri atau pun merusak generasi bangsa dengan cara penyalahgunaan Narkotika.

Faktor yang mendorong sesorang menggunakan Narkotika ada dua yaitu faktor internal meliputi sikap, kepribadian, jenis kelamin, umur, keinginan kenikmatan, perasaan keingintahuan dan untuk melarikan diri dari masalah yang sedang dihadapi, yang kedua faktor eksternal yaitu lingkungan sekitar seperti tempat kerja, keluarga yang berantakan, tingkat ekonomi dan sosial serta tekanan dalam grup. Aturan tentang Narkotika dibuat dengan tujuan ingin menjamin keberadaan obat demi kepentingan bersama untuk kesehatan dan ilmu pengetahuan menghindari penyalahgunaan narkotika itu sendiri. Hal yang menarik adalah adanya kecenderungan untuk mengancamkan sanksi pidana secara bersarnaan antara pidana penjara dengan denda. Sistem seperti ini tidak dikenal dalam pengancaman pidana di KUHP, karena baik pidana penjara maupun pidana denda adalah pidana pokok.

Banyak kasus penyalahgunaan Narkotika di kalangan remaja maupun orang dewasa, maka perlu peran serta masyarakat untuk mencegah dan mengawasi lingkungan sekitar agar tidak terjadi penyalahgunaan narkotika tersebut. Peran masyarakat sangat penting sebagai narasumber untuk melaporkan permasalahan Narkotika, karena masyarakat merupakan orang terdekat yang dalam menjadi saksi dalam penyalahgunaan narkotika, tetapi banyak juga yang tidak mau melaporkan kasus penyalahgunaan Narkotika dikarenakan rasa takut jika anggota keluarga mereka juga terjerat dalam kasus penyalahgunaannya.

Ada beberapa penelitian terdahulu yang relevan dengan penelitian ini Riza Alifianto Kurniawan, (2018) mengkaji tentang pencegahan penyalahgunaan kewenangan penyidik dalam penegakkan hukum tindak pidana Narkotika, selanjutnya (Shilvirichiyant \& Fakultas, 2018); (Idhan \& Muin, 2018) mengungkapkan bahwa mekanisme penyidikan selalu berpedoman dengan Peraturan Kapolri Nomor 14 Tahun 2012 dimulai dari tahap penyelidikan, penyidikan, proses pemanggilan, penangkapan,penggeledahan, penyitaan, pemeriksaan, penahanan, penangguhan penahanan, pembantaran dan pengeluaran tahanan selanjutnya Proses efektivitas penyidikan tindak pidana narkotika selama ini cukup efektif, namun masih perlu ditingkatkan agar pencapaian dapat lebih maksimal.

Sampai saat ini kasus penyalahgunaan narkoba terus meningkat terutama pada kalangan anak muda dan ini terus merusak kognitif generasi, oleh karena itu perlu sosialisasi tentang pemahaman resiko dan sanksi hukum bagi pelaku penyalah gunakan narkoba. Penelitian ini bertujuan untuk menjelaskan kewenangan penyidik kepolisian dalam penyidikan tindak pidana Narkotika dan menjelaskan mekanisme penyidikan di tingkat penyidikan yang dilakukan polisi sebagai penyidik dalam kasus tindak pidana Narkotika 


\section{METODE PENELITIAN}

Penelitian ini didesain menggunakan penelitian secara empiris, yang bertujuan untuk menyalurkan dokumen sedetailnya secara sistematis, komprehensif dan lengkap tentang bagaimana wewenang kepolisian dalam penyidikan tindak pidana Narkotika, juga dengan berpendoman pada peraturan perundang-undangan yang mempunyai hubungan dengan masalah yang diteliti. Sedangkan pendekatan masalah yang digunakan adalah pendekatan antropologi hukum, krirninologi, viktimologi dan penologi (Waluyo, 2002). Data primer adalah data yang didapatkan secara tatap muka di lokasi penelitian dan atau langsung ke sumbemya yaitu jawaban atau keterangan yang dicari oleh penulis. Dalam penelitian juga ini penulis memperoleh data primer menggunakan pertanyaan dan mendapatkan jawaban langsung dari informan atau pemberi informasi yang dalam penelitian ini merupakan anggota kepolisian POLDA BALI. Data primer diperoleh dengan cara peneliti mewawancarai informan atau pemberi informasi yang dalam penelitian ini merupakan anggota kepolisian POLDA BALI, data sekunder adalah data yang mendukung atau memperluas data primer yang di dapatkan dari bahan pustaka seperti undang-undang dan keputusan yang mengikat. Data penelitian diperoleh melalui wawancara bersama beberapa pihak tertentu seperti polisi dengan mekanisme pembicaraan tanya jawab terhadap responden untuk mendapatkan jawaban mengenai penelitian ini. Penganalisaan bahan hukum digunakan denagan teknik deskriptif kualitatif yaitu sebuah metode penelitian yang memanfaatkan data kualitatif yang dijabarkan secara deskriptif dan menghasilkan hasil data yang murni tanpa adanya proses manipulasi atau hal perlakuan lain (Sugiyono, 2013)

\section{HASIL DAN PEMBAHASAN}

\section{Kewenangan Penyidik Kepolisian dalam Penyidikan Tindak Pidana Narkotika}

Wewenang ialah kekuatan untuk bertindak yang didapatkan dari undang-undang berlaku dengan tujuan melakukan kegiatan dan pergerakan hukum. Kewenangan dalam penyidikan biasanya dilakukan oleh pejabat kepolisian, itu dikarenakan penyelidik, penyidik, serta penyidik pembantu berhak melakukan penyelidikan maupun penyidikan dimana hal tersebut dikarenakan aparatur polisi memiliki kuasa atas suatu kewenangan tersebut yaitu dalam hal penyidikan dan penyelidikan. Kewenangan yang dimiliki oleh seorang pejabat atau institusi tersebut didapatkan dari kekuasaan legislatif atau dari kekuasaan eksekutif administrasi. Sebelum adanya penahan perlu dilakukan adanya suatu penyidikan danjuga penyelidikan terlebih dahulu. Kewenangan bukan hanya dimaksudkan untuk melakukan suatu keinginan atas kekuasaan dari diri sendiri. Tetapi kewenangan juga dimaksudkan yaitu untuk memaparkan dan penegakan hukum panutan yang sesuai perintah memutuskan pengawasan yurisdiksi atau kekuasaan.

Penyelidikan adalah penentu dari perbuatan bisa dikatakan suatu tindak pidana atau tidak dengan bertujuan untuk mengetahui siapa yang sudah melakukan kegiatan kejahatan dan memberi buktinya tentang permasalahan yang sudah dilakukan. Proses penyidikan ini biasanya dilakukan oleh anggota Polri. Antara penyidikan dan penyelidikan merniliki suatu keterkaitan yang sama yaitu samasama mendukung kesuksesan suatu penyidikan. Untuk tercapainya tujuan tersebut penyidik akan menampung informasi dengan informasi asli atau kejadian-kejadian tertentu (Harum, 1991). Penyidikan merupakan serangkaian tindakan yang dilakukan oleh penegak hukum atau Polri atau pejabat yang lain yang ditunjuk sesuai dengan kewenangannya yang diberikan rugas oleh undangundang yang dilakukan melalui beberapa proses diantaranya dari penyelidikan dan telah mendapatkan bukti-bukti yang memberikan dukungan dan telah mendapatkan tersangka atau orang yang tel ah diduga sebagai seorang yang telah melakukan tindak pidana. kewenangan penyidik polri dalam tindak pidana narkoba yaitu mengikuti UU No.35 Tahun 2009 tentang Narkotika. Wewenang penyidik sebagaimana yang sudah diatur yaitu dalam pasal 81, pasal 84, pasal 87, pasal 90, pasal 92 UU No.35 Tahun 2009 tentang Narkotika.

Kewenangan penyidikan ialah suatu yang penting mengenai bagaimana isi sebenamya di dalam tindak pidana dan juga dikategorikan dalam tindak pidana narkotika. Bila suatu penyidikan tidak dapat dikendalikan karena ketidaktahuan dari batasan siapa penyidikan dan akhirnya memperlihatkan tumpang tindih dan tarik ulur kewenangan, maka proses pembersihan narkotika akan tidak dapat dikendalikan. Karena itu perlu diketahui bahwa antara penyidik polri dengan BNN mempunyai wewenang yang berbeda, BNN mendapatkan wewenang untuk melakukan penyelidikan dan penyidikan terhadap penyalahgunaan Narkotika. Dimana wewenang tersebut sudah tertera pada UU 
No.35 Tahun 2009, terdapat pada pasal 71, pasal 75, dan pasal 80 UU No.35 Tahun 2009 tentang Narkotika.

Polisi dan BNN mempunyai wewenang masing-masing dalarn melakukan penyidikan. Yang diperlukan adalah koordinasi antara Polisi dan BNN. Koordinasi siapa yang akan melakukan penyidikan selanjutnya. Polisi dan BNN melakukan kerjasama untuk menangkap para pelaku tindak pidana Narkotika, kerjasama inilah yang harus dikoordinasikan. Karena ini dikatakan kerjasama, jadi pihak Polisi memberitahukan kepada BNN apa yang dilakukan polisi terkait penyidikan tersebut, dengan kata lain saat kondisi itu, siapa yang mempunyai hak atau bagaimana pelaksanaan tidak diatur secara detail.

\section{Mekanisme Penyidikan di Tingkat Penyidikan yang Dilakukan Polisi sebagai Penyidik dalam Kasus Tindak Pidana Narkotika}

Untuk memulainya mekanisme penyidikan Tindak Pidana Narkotika, perlu adanya Standar Operasional Prosedur (SOP) adalah cara yang dipergunakan untuk memberi kepastian mengenai kegiatan operasional organisasi atau perusahaan berjalan dengan mulus. Tahap pertama dilakukan oleh penyidik adalah penyelidikan. Untuk dapat dilakukan tindakan penyidikan, yang dilakukan terlebih dahulu ialah penyelidikan oleh pejabat penyidik, dengan keinginan untuk mengambil dan menyimpan bukti pemulaan atau bukti yang cukup agar diJanjutkan di penyidik, lalu melakukan pemeriksaan atau pengolahan temp at kejadian perkara (Harapan, 2009). Setelah diketahui bahwa penyelidikan selesai dilakukan dan dianggap cukup sebagai bukti permulaan tindak pidana, proses selanjutnya yang dilakukan adalah proses penindakan dan pemeriksaan. Penyidikan ialah suatu bagian penting dalam strukrur penyidikan yang harus dilakukan sebelum dilakukannya pembuktian terhadap yang diduga telah terjadinya suatu tindak pidana. Karena dengan adanya proses penyidikan tidak bisa dilepaskan dari adanya ketentuan perundang-undangan yang mengatur mengenai tindak pidanannya (Nugroho, 2012).

Penindakan dan pemeriksaan yang dilakukan oleh penyidik menurut Anggota kepolisian yaitu Bapak Budi pada tanggal 10 Desember 2020 di Polda Bali yaitu mengikuti Standar Operasional Prosedur (SOP) atau buku pedoman yang dibuat oleh negara, yaitu pemanggilan tersangka dan sanksi, penangkapan tersangka yang terduga melakukan suaru tindak pidana yang dapat dilihat dari bukti awal yang cukup, penahanan, Penggeledahan mempunyai tujuan untuk mencari dan menemukan bukti, melakukan proses penyitaan, melakukan pemeriksaan untuk mendapatkan kejelasan atau keterangan dari tersangka atau sanksi yang dituangkan dalam berita acara pemeriksaan (Mulyadi, 2009).

Setelah penyidikan selesai dilakukan selanjutnya dilakukan proses penyelesaian dan penyerahan dokumen perkara. Adapun struktur isi dokumen perkara yang terdiri dari cover dokumen perkara, penentuan halaman dokumen perkara, isi dokumen perkara yang berisikan berita acara lanjut, laporan polisi, berita acara(tindakan penyidik), surat-sura (biasa perintah) daftar saksi, daftar tersangka, daftar barang bukti. Setelah semua dokumen sudah tersusun dibuatlah pemberkasan yaitu kegiatan susunan hasil penyidikan dalam bentuk tulisan. Setelah hasil penyidikan sudah tersusun kemudian penyerahan berkas perkara. Kegiatan ini adalah kegiatan pengiriman berkas perkara, yang dikirimkan kepada penuntut umum dengan maksud menyerahkan tanggung jawab atas tersangka.

\section{SIMPULAN DAN SARAN}

\section{Simpulan}

Dari hasil analisis data dapat disimpulakan bahwa Kewenangan penyidik kepolisian saat menyidik tindak pidana narkoba ialah mengikuti pasal 1ayat 1 KUHAP, dan Pasal 81 UU no.35 Tahun 2009 tentang Narkotika. Polisi mendapatkan kewenangan untuk membantu masyarakat yaitu ikut serta dalam penyidikan maupun penyelidikan guna memberikan rasa aman kepada masyarakat. Anggota kepolisian daerah Bali, I Ketut Badra, pada tanggal 1 Desember 2020 juga mengatakan bahwa kewenangan Penyidik Polri dalam tindak pidana Narkotika yaitu mengikuti UU No.35 Tahun 2009 tentang Narkotika. Mekanisme dalam kasus tindak pidana narkotika mengacu pada pasal 81, pasal 84, pasal 87, pasal 90, pasal 92 UU No.35 Tahun 2009 tentang arkotika. Anggota Polri yaitu Bapak Budi pada tanggal 10 Desember 2020 di Polda Bali, Kepolisian dalam melaksanakan penyidikan, mengikuti mekanisme yang tertera di buku pendoman yang dibuat Negara yang dalam hal proses pemeriksaan mekanisme penyidikan dibagi dalam tiga proses yaitu proses penyelidikan, proses 
penindakan dan pemeriksaan dan juga proses terakhir yaitu penyelesaian dan penyerahan berkas perkara.

\section{Saran}

Dari hasil penelitian di atas, adapun saran yang diberikan yaitu Berkaitan dengan kewenangan penyidik polri dalam tindak pidana narkotika, pihak kepolisian diharapkan memberikan ceramah tidak hanya ke daerah-daerah besar saja, polisi juga perlu memberikan ceramah ke desa-desa kecil untuk mencegah penyebaran Narkotika terjadi. Masyarakat diharapkan dapat membantu pihak kepolisian untuk mengungkapkan perkara pidana. Seperti memberikan informasi tempat, memberikan informasi pelaku dan juga bisa ikut melakukan penyidikan seperti mengawasi dari suatu tempat atau bahkan mengawasi dari rumah saja. Masyarakat juga diharapkan untuk tidak menutupi kasus oleh karena alasan takut keluarga atau kerabat juga terjerat dalam kasus Narkotika, karena justru dengan melaporkan kasus tersebut kepada pihak kepolisian, polisi dapat mengambil tindakan apa yang seharusnya diterima.

\section{DAFfAR PUSTAKA}

H.S, S., \& Nurbani, E. S. (2013). Penerapan Teori Hukum pada Penelitian Tesis dan Disertasi. Jakarta: Rajawali Pers.

Harapan, Y. (2009). Pembahasan Permasalahan dan Penerapan KUHP penyidikan dan penuntutan. Jakarta: Sinar Grafika.

Harum, M. H. (1991). Penyidik dan Penuntut dalam Proses Pidana. Jakarta: Rineka Cipta.

Idhan, \& Muin, I. (2018). Efektifitas Penyidikan Tindak Pidana Narkotika: Studi Kasus Polrestabes Makassar. Jurnal Petitum, 6(2), 98-111.

Marbun, S. (1997). Peradilan Administrasi Negara dan Upaya Administrasi di Indonesia. Yogyakarta: Liberty.

Mulyadi, L. (2009). Hukum Acara Pidana Normatif Teoritis Prakiik dan Perasalahannya. Jakarta: Sinar Grafik.

Nugroho, H. (2012). Integralisasi Penyidikan Tindak Pidana Korupsi di Indonesia. Jakarta :Media Aksara Prima.

Riza Alifianto Kurniawan. (2018). Pencegahan Penyalahgunaan Kewenangan Penyidik dalam Penegakkan Hukum Tindak Pidana Narkotika. Jurnal Masalah - Masalah Hukum, 47(2), 111117.

Shilvirichiyant, \& Fakultas, A. A. (2018). Peranan Penyidik Dalam Penanganan Penyalahgunaan Narkoba di Wilayah Hukum Polisi Resort Kuantan Singingi. Jurnal UIR Law Review, 2(1), $244-255$.

Sugiyono. (2013). Metode Penelitian Pendidikan Pendekatan Kuantitatif dan Kualitatif. Alfabeta.

Waluyo, B. (2002). Penelitian Hukum Praktek. Sinar Grafika. 